\title{
IRISH STUDIES IN SPAIN - 2017
}

\section{Marisol Morales-Ladrón (ed.)}

Copyright (c) 2018 by the authors. This text may be archived and redistributed both in electronic form and in hard copy, provided that the author and journal are properly cited and no fee is charged for access.

\section{Introduction}

Marisol Morales-Ladrón

Ireland and Dysfunction: Critical Explorations in Literature and Film

Asier Altuna-García de Salazar, ed.

Germán Asensio Peral

Nordic Irish Studies 15.1 (2016). Special Issue: Discourses of Inclusion and Exclusion: Artistic Renderings of Marginal Identities in Ireland

Pilar Villar-Argáiz, ed.

Maureen O’Connor

Migrant Shores: Irish, Moroccan \& Galician Poetry

Manuela Palacios González, ed.

Regina M. Ponciano

National Identities and Imperfections in Contemporary Irish Literature. Unbecoming Irishness

Luz Mar González-Arias, ed.

Giovanna Tallone

Shaw: The Journal of Bernard Shaw Studies 37.1 (2017). Shaw and Classical Literature Gustavo A. Rodríguez Martín, ed.

Audrey McNamara

En busca de la Isla Esmeralda. Diccionario sentimental de la cultura irlandesa

Antonio Rivero Taravillo

José Francisco Fernández 


\section{Introduction}

\section{Marisol Morales Ladrón}

Border issues have been the source of deep anxiety and distress in Ireland in the past few months. The year opened with British Prime Minister Theresa May confirming the disconnection of Britain from the European Union after Brexit, which inevitably involved the negotiation of the terms upon which the Northern Irish border had been established. While Ireland has been involved in an intense inward evaluation of what an undesirable hard border would entail, it has also strategically expanded outwards, looking for the support of other European countries with which to strengthen ties, including Spain. In fact, the year started with a meeting on January $12^{\text {th }}$ between former Taoiseach Enda Kenny and Spanish Prime Minister Mariano Rajoy in Madrid, with the intention of minimizing the potential side-effects of Brexit, enhancing business networking, preserving mutual interests and fostering the indivisibility of the European project. At present, Brexit negotiations have moved forward to another stage, which involve guaranteeing the protection of the peace process and of the economy of the whole island, and the refusal to erect a hard border.

Major changes have also occurred in the government of the Irish nation. Leo Varadkar, Ireland's youngest Taoiseach in history, the first coming from an ethnic minority and also the first one to declare himself openly gay, was appointed in mid-June as the new Prime Minister, succeeding former Fine Gael leader Enda Kenny. Among other political concerns, Varadkar has held the responsibility of dealing with the long-demanded Repeal of the Eight Amendment of the Irish Constitution, that condemns abortion and limits the choices of women who find themselves in an unwanted pregnancy. A referendum will take place around May-June 2018, which could result in the passing of a Bill that could allow pregnant women up to twelve weeks to have an abortion and includes a number of other clauses that were also pleaded. In spite of the political advances and negotiations, last December, the Taoiseach declared that he would not reveal his personal opinion on the matter and that he would allow dissenting voices within his cabinet to vote against the proposal.

On a different note, and as I write these lines, news of the recent Laureate for Irish Fiction come through. Sebastian Barry, a writer of profound truths and genuine insight into the human condition will succeed Anne Enright for the next three years. His recognition that "we are in an unexpected golden age of Irish prose writing" (Doyle 2018) contrasts with his anxieties at an early stage of his career when, as he has admitted: "There's a part of me when I was young that would happily have poisoned the soup of every other writer, just to get them out of the way" (Heaney 2018). Such success of the Irish letters can only be matched by Edna O'Brien's PEN literary award, in the same week, for a lifetime achievement. But throughout the year, other literary prizes have also acknowledged the work of high profile authors, among whom we can include Benjamin Black - John Banville's fictional penname and alter ego -, who was awarded the RBA of noir fiction for his novel Sin last September, and Sebastian Barry and Mike McCormack, who were longlisted for the Man Booker Prize last July.

As regards cultural activities organized in Spain and in connection with Irish studies, I should first refer to an extraordinary event that took place in Asturias last October-November. Irish extremely genuine and transgressive artist, Amanda Coogan, performed "Spit, Spit, Scrub, Scrub" in the Niemeyer Centre, as part of the exhibition "I'll sing you a song from around the town", which was curated by AEDEI member Luz Mar González Arias. Coogan's durational performance intended to highlight body self-control, the abject and gender biases in contemporary society. The Niemeyer centre also showcased the documentary "Amanda Coogan: Long Now", directed by Paddy Cahill, which explored the function of time in her durational performances. Further cultural celebrations in Madrid, mostly supported by the Irish Embassy, involved the "Navideña Feria Internacional de las Culturas", which took place 
in December in El Matadero, with a dramatized reading of W. B. Yeat's On Baile Strand, Irish music played by Púca Óg and Compañía Trotadanzas, and Irish dancing performed by the Irish Treble dancers. A lot of other activities have also proliferated in different parts of Spain all through the year, such as Bloomsday celebrations, Irish music Festivals and Conferences and seminars on Irish studies, including the traditional annual meeting of AEDEI, which was organized by the University of La Rioja.

Finally, the number of publications dealing with the literature, culture, music and cinema of Ireland in the 2017 has increased in Spain both in quantity and scope, showcasing a wide array of interests across different genres and disciplines. The present section includes, therefore, six of those monographs or special journal issues, and inevitably has to leave for next year recently published Spanish translations of Irish texts, such as: Máximo Aláez Corral's Desnudo, by Nuala Ní Chonchúir; Luz Mar González Arias's Un almuerzo literario y otros cuentos, by Éilís Ní Dhuibhne; and José Francisco Fernández's Cómo es, by Samuel Beckett, among others. I can only end this short overview of the state of Irish Studies in Spain in 2017 congratulating every author, editor and contributor, for their achievements, and encouraging a new breath of Irish scholars, to continue producing further critical studies that will contribute to enhance and enrich the field of Irish Studies in Spain.

\section{Works Cited}
Doyle, Martin. "Sebastian Barry Revealed as New Laureate for Irish Fiction." The Irish $\begin{array}{llllll}\text { Times. } & 8 & \text { February } & 2018 . & 19 & \text { February }\end{array} 2018$. https://www.irishtimes.com/culture/books/sebastian-barry-revealed-as-new-laureatefor-irish-fiction-1.3383687\#.WnxJSL9FMTF.twitter.

Heaney, Mick. "Sebastian Barry: 'Part of me when I was young would have poisoned the soup of every other writer"”. The Irish Times. 10 February 2018. 19 February 2018. https://www.irishtimes.com/culture/books/sebastian-barry-part-of-me-when-i-wasyoung-would-have-poisoned-the-soup-of-every-other-writer-1.3383391.

Marisol Morales-Ladrón is Senior lecturer at the University of Alcalá (Spain). Her areas of research include contemporary Irish literature, gender studies and the interrelationship between literature and psychology. She has written the books Breve introducción a la literatura comparada (1999) and Las poéticas de James Joyce y Luis Martín-Santos (2005). She has edited the volumes Postcolonial and Gender Perspectives in Irish Studies (2007) and Family and Dysfunction in Contemporary Irish Narrative and Film (2016), and has also coedited the monograph Glocal Ireland: Current Perspectives on Literature and the Visual arts (2011), as well as two studies on feminist criticism: Mosaicos y taraceas: Desconstrucción feminista de los discursos del género (2000) and (Trans)formaciones de las sexualidades y el género (2001). She has published articles on a variety of English and Irish authors, which have appeared in peer-reviewed journals. At present, she serves as Vice-President for Academic and Student Affairs at the University of Alcalá and has held previous positions as Head of Department, Director of Academic Affairs, Chair of AEDEI, and executive member of the Boards of several national and international associations.

marisol.morales@uah.es 
Ireland and Dysfunction: Critical Explorations in Literature and Film

Edited by Asier Altuna-García de Salazar

Newcastle upon Tyne: Cambridge Scholars Publishing, 2017. 276 pp.

ISBN: 1-4437-1293-X

\section{Reviewer: Germán Asensio Peral (University of Almería, Spain)}

While the term "dysfunction" has been surprisingly alien to literary and film studies until very recently, it is recurrent in fields as disparate as medical sciences and sociology. In sociology, for example, the use of the term derives from the social theory of functionalism, which sees society as an all-inclusive, ever-changing compound striving to achieve stability and harmony through the union of its parts. As proposed by Merton (1968) and Berger (1963), dysfunction thus consists of the inability - or, in some cases, the incapacity - to effect this process of cohesion in society as a whole, but also in more particular threads of the social fabric such as the political system, the family, or individual relationships, which in turn are often perceived as constructs. Dysfunction occurs when a part or parts of this social fabric fail to function as expected by other members of the same group or culture.

Because literature and film are forms which are often preoccupied with the development and intrinsic nature of human society, they lend themselves as an optimal medium for the representation of the process and consequences of dysfunction in a given group. The contributions included in Ireland and Dysfunction: Critical Explorations in Literature and Film, edited by Asier Altuna-García de Salazar and inspired by the proceedings of the XIII International Conference of the Spanish Association of Irish Studies (University of Deusto, Bilbao, 2014), cast additional light on the concept of dysfunction by dovetailing it with issues of the Irish case. In the editor's Introduction, Altuna states that "[d]ysfunction might be regarded as part and parcel of a portrayal of a landscape of trauma and crisis that may have been traditionally repressed in Ireland at large. But, dysfunction also envisages mediation, managing, transcending and healing" (vii). Mindful of this duality, the chapters included in this volume explore dysfunction in the Irish context over the twentieth and twenty-first centuries. This is done by examining a number of literary and visual genres, including novels, plays, documentaries, TV series and films, but also by closely scrutinizing the lives of major literary figures.

The first section, "Dysfunction and Cinema in Ireland Today", sees Irish cinema as a representative force of dysfunction in Ireland in relation to the concept of the "other". On the one hand, Pilar Villar Argáiz's essay "Cinematic Representations of Immigrants in Irish Ethnographic Films: Alan Grossman and Áine O'Brien's Documentary Work” explicitly seeks to situate recent immigration into Ireland as central to the understanding of racial and ethnic dysfunctionality set against self-perceived ideas of Irishness. This essay is methodologically sound, being based primarily on contemporary critical race theory as well as on the theory and practice of documentary films. On the other hand, Rosa GonzálezCasademont's "Intimations of Personal and Social Anomie in Kirsten Sheridan's Irish-set Feature Films" continues the cinematographic theme by discussing Sheridan's Irish-set films Disco Pigs (2001) and Dollhouse (2012) in relation to the critical concept of anomie, which she prefers over dysfunction due to the normativity and staticity of the latter. Even though she finds thematic divergences between the two movies, she hints at how the films problematize "the widespread perception of Irishness as a site of stable family life and community bonds" (41).

The second section, "Dysfunction: Sexuality, Dislocation and Space", sees Irish literature and film as a site for the observation and analysis of dysfunctional processes of 
sexuality and (dis)location. Firstly, Aintzane Legarreta-Mentxaka's compelling essay, "Sexuality and Dysfunction in Kate O'Brien", considers the interrelation of O'Brien's life and works and how one mirrors the other. Legarreta Mentxaka's essay is an exploration of how O'Brien's novels, in their subversive representation of love, family and sexuality, both challenge and are hindered by the heavily policed context of the new Ireland. Secondly, Eibhear Walshe's illuminating essay "Kate O'Brien and Spain" focuses on the influence of Spain on O'Brien's life and writings. He argues that "Spain provided an escape, an alternative space to the Ireland of the early twentieth-century for O'Brien and for her protagonists" (71). In his analysis of three of O'Brien's novels involving Spain (Mary Lavelle, 1936; Farewell Spain, 1937; That Lady, 1946), Walshe traces O'Brien's relationship with the country, a land she venerated feverishly but of which she also came to be highly critical during and after the Spanish Civil War. Thirdly, Stephanie Schwerter's contribution, "Representing a Dysfunctional City: Belfast in Texts and Images", aptly switches the topographical focus to Northern Ireland and Belfast while returning to the cinematographic theme. Her study explores traditional visions of Belfast as home to a socially and ideologically disrupted people through an analysis of Robert McLiam Wilson's Eureka Street (1996) and the 1999 miniseries adaptation of this directed by Adrian Shergold, the arguments here supported by Bakhtin's theory of carnivalisation.

The third section of the volume, "Dysfunction: Family, Home and Memory", opens with José M. Yebra's essay "Family Dysfunctionality and New Ireland in Colm Tóibín's Mothers and Sons", which looks at the dysfunction that exists in Irish families as represented in the collection of stories Mothers and Sons (2006), as well as in his 2012 novella The Testament of Mary. He does so by drawing on Cathy Caruth's trauma theory and examines the processes of ideological oppression of counter-hegemonic family structures and modes of sexuality. Sara Martín-Ruiz's "Family and Dysfunction in Edna O'Brien's A Pagan Place" seeks to understand O'Brien's 1970 novel as being a "forerunner of a trend in Irish literature which would take hold decades later" (127). With the support of psychological and medical sciences, she provides a wide-ranging analytical study of the dysfunctional family in the novel on an individual and collective level. She cleverly manages to frame the family's gradual disintegration amidst the profoundly patriarchal and overwhelming Catholic background of de Valera's Ireland which is symbolised by the 1937 Constitution. Inés Praga-Terente's invigorating essay "The (Dys)function of Memory: Glimpses of Childhood in John McGahern's Memoir and Edna O'Brien's Country Girl" reads these two works (published in 2005 and 2012, respectively) as representative examples of life writing. Both McGahern and O'Brien grew up in the intellectually and morally asphyxiating mid-twentieth century context of Ireland, and depict memory and nostalgia as lacunae of trauma and dysfunction. Burcu Gülüm Tekin's "The Silent Mother of the Dysfunctional Family: a Feminist Approach to Roddy Doyle's Paddy Clarke Ha Ha Ha (1993)" then closes the third section. Critically informed by the trauma and feminist theories of Cathy Caruth and Adrienne Rich, she examines the transition from harmony to violence and dysfunction in Paddy's family. Most importantly, however, she argues that silence on the part of the mother reverberates in Paddy's narrative in the form of narrative gaps which blur his explicitness in the representation of domestic violence.

The fourth section, "Dysfunction: Struggles and Quests" illustrates dysfunction as arising from, or resulting in, quests and struggles on a textual and biographical level. María Gaviña-Costero opens the section with the essay "In the Beginning Was Silence: Brian Friel's Revisitiation of the Artist". She revisits Friel's 1997 Give Me Your Answer, Do! and challenges contemporary negative appreciations of the work, which for her is "one of Friel's more introspective and less socially concerned plays" (185). Through textual analysis, Gaviña-Costero sees the play's powerful autobiographical undertones as mirroring Friel's 
own life-long preoccupation with his own art. Secondly, María José Carrera's essay “"Back or on, I don't know': Samuel Beckett's From an Abandoned Work" compellingly interprets Beckett's 1958 short-fiction-turned-play from an autographic perspective rather than following previous psychoanalytic trends. Carrera examines the overtly experimental narrative disruption present in From an Abandoned Work as a textual echo of Beckett's own writing career. Olga Fernández-Vicente's "James Joyce and Pío Baroja's Dysfunctional Relationships with their Countries: A Quest for Independence" brings the fourth section to a close. This essay is a comparative study of two key authors in Irish and Spanish literature of the beginning of the twentieth century. While she notes many similarities in the writing careers and personal lives of the two authors, she also draws attention to some clear differences. In particular, she points out Joyce's success in his quest for independence as opposed to Baroja, who "got trapped in the nets he had tried to fly by and saw himself linked to the far right" (238), which eventually resulted in his artistic decline and subsequent exclusion from the literary pantheon.

The book concludes with an interview with Billy O'Callaghan, conducted by Marisol Morales-Ladrón. O'Callaghan, author of three short story collections, a work of non-fiction and, more recently, a novel, talks at length about his diligent and steadfast writing process, his influences and inspirations (both literary and otherwise) and his career as a whole. In line with the general topic of the volume, he discusses the recurrence in his stories of the tropes of death, grief and loss in the shape of illnesses and relationship break-ups. He also explains how his characters attempt to painstakingly overcome these dysfunctional events in their lives.

The importance of a work such as Ireland and Dysfunction: Critical Explorations in Literature and Film is justified not only by the palpable academic quality of its contributions but also by its state-of-the-art interdisciplinary approach. Not only does it offer ample and balanced variety in the intricate study of literary and cinematographic art, but it also draws on and is sustained by honest contributions from other scientific realms. All in all, this is a wellconsidered volume which offers a kaleidoscopic and panoramic view of dysfunction as represented in the works of art analysed therein, and which also revitalises academic production on Irish literature and film from a Spanish-based perspective.

\section{Works cited}

Merton, Robert K. Social Theory and Social Structure. New York: The Free Press, 1967. Berger, Peter L. Invitation to Sociology: A Humanistic Perspective. New York: Doubleday, 1963.

German Asensio Peral obtained both his bachelor's degree and his Master's Degree in English Studies at the University of Almería (Spain) with an honorary distinction. He is currently working on his Ph.D. dissertation on Irish writer Brian O'Nolan and his journalistic production as Myles na gCopaleen. He is currently a Research Fellow at the University of Almería (Department of Philology). His research focuses on the field of Irish literature with a particular interest in O'Nolan/O'Brien/na gCopaleen and has published articles and delivered papers on O'Nolan's novels, short stories and columns.

german.asensio@ual.es 
Nordic Irish Studies 15. 1 (2016). Special Issue: Discourses of Inclusion and Exclusion: Artistic Renderings of Marginal Identities in Ireland

Edited by Pilar Villar-Argáiz

\section{Reviewer: Maureen O’Connor (University College Cork, Ireland)}

In her introduction to this 2016 special issue of Nordic Irish Studies 15.1, "Discourses of Inclusion and Exclusion: Artistic Renderings of Marginal Identities in Ireland", guest-editor Pilar Villar-Argáiz states that marginality has been a defining feature of Irish identity from the early articulations of the field known as Irish Studies. Villar-Argáiz also notes the ways in which categories of inclusion, exclusion, and marginality have increased and developed further complexities in twenty-first-century, multicultural Ireland. Post-colonial, postindependence Ireland, many of the essays suggest, has failed to "cherish all of [its] children" or to come to terms with the damage inflicted on many of its own over the course of the twentieth century. This failure ramifies into the present and future, as historical traumas, violence, and injustice go unacknowledged, never mind expiated. These traumas are, instead, replicated, adding new victims to the state's traditional categories of the abject. It is an interesting time to look again at conceptions of the marginal, a category of analysis that might seem out of date, but the dangers of exclusion are only increasing, as what counts as the "centre" contracts with alarming speed and becomes more impenetrable every day. The rise and dominance of social media in much of the world has created the impression that it is possible for everyone and anyone to find his or her group online, to find a "place" in which to belong. These virtual "clubs" promise respect, acceptance, and personal connection with the like-minded, no matter how far outside of the mainstream, even as material experience in the real world steadily degrades for those excluded from not only power and representation, but also, in some cases, basic rights and access to essential resources. Defining the mainstream becomes more difficult as shared experiences of culture, entertainment, and political debate grow ever more fragmented, limited, and specialised. What is often promoted as a liberatory phenomenon of unbridled creativity and connection actually militates against genuine engagement and communal action, ultimately protecting the interests of the new gilded-age phenomenon of the "one-percent". Ireland's late twentieth-century economic boom brought the country in line with other "developed" countries in terms of income inequality, thanks to an enthusiastic embrace of neoliberalism and free-market values. As Ireland emerges from the inevitable post-boom crash, not all boats are rising and many are, in fact, boat-less. The rising tide threatens to swamp an unprecedented number of Irish citizens as the level of homelessness and of families accessing emergency accommodation and "soup kitchens" breaks records. The marginal will always be with us.

The categories of marginality that organise the analyses undertaken in this special issue are gender (which emerges as almost grimly persistent in the majority of contributions across subsections), religion, class, ability, ideology, age, and exile. The first section, "Gender and Marginality", comprises nearly half of the contributions and opens with Auxiliadora Pérez Vides's powerful essay, "Magdalene Otherness and Ethical Turns in Stephen Frears's Philomena". The research Pérez has been conducting for years on Ireland's carceral regime of Magdalene laundries and Mother and Baby Homes is brought to bear on a reading of Frears's successful 2013 film, Philomena. Pérez contextualises the film historically, politically, socially, and culturally, providing examples of artistic responses in fiction, drama, and film to the revelations in the 1990s of not only the abuses perpetrated by these institutions, but also the continuing suffering of their surviving victims. Pérez suggests that the "Magdalene "Otherness" presented in the film is not simply filling a "historical gap", but is also a "current 
reality that needs to be solved within the ethical agenda of the nation". In its sophisticated analysis, the essay deploys Giorgio Agamben's biopolitical concept of "the state of exception", Julia Kristeva's "abject", and Judith Butler's critique of the "exclusionary matrix", which draws on Michel Foucault's work on technologies of punishment. The Magdalenes, Pérez argues, are a literalisation of Butler's "zones of social exclusion". The political urgency and power of cultural representation are persuasively asserted in this call to action that provides an invigorating entry into the special issue. Philomena was based on the experiences of a real woman.

Marisol Morales-Ladrón, in “Mary Morrissy's The Rising of Bella Casey, or How Women Have Been Written Out of History", also considers an artistic rendering of a woman's life. Mary Morrissy's 2013 novel fictionalises the life of the sister of playwright Seán Casey, Bella, about whom much less is known than is the case for Frears's still-living subject. Morales-Ladrón helpfully positions Morrissy's novel vis-à-vis other recent approaches to historiography in contemporary Irish women's writing, which presents an alternative approach to writing forgotten women back into historical narratives. In this decade of commemoration there is a special urgency to reconsidering narratives of the nation's founding a century ago, accounts which have accreted into a near-mythological paean to violent and militarist masculinity, an accretion partly achieved by erasing the considerable contributions and sacrifices made by women. As Jacques Derrida argues in Spectres of Marx, our relationship to the dead is one of responsibility. Similarly, Morales-Ladrón asserts that "reconstruction of the past is a repossession of the present". Remembering is a political and ethical act. It is damaging and hubristic to imagine that we are independent of the past, including the pasts of those who preceded us.

Beatriz Rubio Martinez's “Trauma and (Re)Construction of the Past in Deirdre Madden's Time Present, Time Past" also traces the power of reconstructions of the past, especially when that past is traumatic. In Madden's novel, also published in 2013, however, Rubio finds a text that takes its time coming anything close to an assuasive vision of the value and function of memory. This reading applies a welcome dash of astringent to overly positive representations of the process of coming to terms with the past, which is slow, painful, and necessarily incomplete. Madden's female characters initially use memory "more as a device for idealisation than a necessary journey into understanding and healing". The women in the novel find it easier to address collective wrongs than to face individual fears. Community is not a simple evil or good, and Rubio's analysis of the complex dynamic between the individual characters and their relationships to family and village does much to bring needed attention to a recent novel which, like Morrissy's, has not received the critical attention it deserves.

It is not possible in the space available to discuss each essay, but the three identified so far represent the strongest entries in the first section, which suffers somewhat from similar themes and approaches being duplicated to uneven effects. It might have been prudent to include fewer, but longer, more fully developed contributions. This could also have the effect of bringing greater clarity to the special issue. So much of the discussion across the contributions comes back to gender and sexuality that further narrowing the overall focus of the issue might have guarded against the danger of the "marginal" becoming a diffuse, and all-encompassing organising principle. For example, Britta Olinder's fine essay, "Inclusion and Marginalisation: John Hewitt as an Ulster Protestant in Opposition", which appears in the middle section "Dissidents, Apolitical Subjects and Social Misfits", has much of interest to say about Hewitt's own ambiguous self-identification, his shifting and recalcitrant sectarian, political, and cultural allegiances. However, it is problematic, if not borderline offensive, to suggest that a white man born into relative material comfort and privilege is "marginalised" in the same way as are victims of the Magdalene system or people of colour, including migrants. 
The essay makes clear that Hewitt's identity as "marginal man" living between two "antagonistic cultures" is a position deliberately and consciously chosen, a position which, while politically provocative and artistically productive, was not something imposed on him that determined his status or limited his opportunities. He was, undeniably, an "outsider", but one who chose to set himself against the mainstream. The insights of this essay are potentially undermined by its inclusion amongst the others in the issue, a sign of the problem of a rubric at once too confining and too broad. At the very least, a stronger editorial hand could have suggested some finessing of this contribution's argument, especially in relationship to other essays.

Another noteworthy essay in this second section is Hedwig Schwall's "Marginal(ising) Mothers and Transitional Objects in William Trevor's Cheating at Canasta". Schwall uses object theory and the "good-enough" mother, theories and figures derived from child psychology, particularly the pioneering work of Donald Winnicott, as interpreted by Christopher Bollas, in her reading of Trevor's 2007 novel. Again, gender emerges as informing the discussion of religion and family and, even, the gentle comedy of Trevor's text. The inclusion of inanimate objects in the category of the marginalised and the connection between the thing and the child are some of the more striking elements of Schwall's delightful analysis. While the discursive apparatus is psychoanalytic, the essay indicates the potential for extending this kind of reading into a recent area of ecofeminist literary work, feminist new materialism, which argues for the dissolution of categories beyond gender and race to those that distinguish between what we have come to assume is the "animate" and the "inanimate", an approach with special significance in Irish women's textual practice.

The last section, "Marginalities in Exile", comprises two contributions, including the concluding piece, by guest editor Villar-Argáiz, "Humanising the lived experience of migrants': An Interview with Alan Grossman and Áine O'Brien". This thoughtful conversation with the documentary makers about migration and multiculturalism in contemporary Ireland neatly circles back to filmic representations of marginality and exclusion in an Irish context, and also returns to questions of gender as well as sexuality. The unflinching yet hopeful intelligence and vision of the filmmakers provides an articulate, forward-looking conclusion to this special issue's extended contemplation of Ireland's vexed and continuing struggle to become the inclusive society envisioned by the 1916 Proclamation, which resolved to "cherish all of the children of the nation equally".

Maureen O'Connor lectures in the School of English in University College Cork. She is the author of The Female and the Species: The Animal in Irish Women's Writing (2010), and has most recently co-edited, with Derek Gladwin, of a special issue of the Canadian Journal of Irish Studies, "Irish Studies and the Environmental Humanities", 40.1 (2018). She has published widely in Irish Studies and has recently completed a book-length study of Edna O'Brien's fiction. She is also working on a monograph on nature and nation in the writing of Irish first-wave feminists, including Eva Gore-Booth, Margaret Cousins, Charlotte Despard, and Alice Stopford Green.

maureen.oconnor@ucc.ie 
Migrant Shores: Irish, Moroccan \& Galician Poetry

Edited by Manuela Palacios

Cliffs of Moher: Salmon Poetry, 2017. 138 pp. With calligraphies by Hachemi Mokrane.

ISBN: 978-1-910669-96-9

\section{Reviewer: Regina M. Ponciano (University of Santiago de Compostela, Spain)}

The editor of Migrant Shores: Irish, Moroccan \& Galician Poetry, Manuela Palacios, is no foreigner in the world of anthologies, translation, or the poetic borderlands of these three Atlantic communities. After To the Winds our Sails: Irish Writers Translate Galician Poetry (2010; co-edited with Mary O'Donnell), Forked Tongues: Galician, Basque and Catalan Women's Poetry in Translations by Irish Writers (2012), Six Galician Poets (2016; translated by Keith Payne), and Los Ritos de los Sentidos (2016; co-edited with Jaouad Elouafi, Bahi Takkouche, and Arturo Casas), amongst others, the present volume is Palacios' latest anthology that seeks to redress the literary canons that have marginalized Galician, Irish, and Moroccan poets in general, and women poets in particular. In line with this trajectory, Migrant Shores provides us with a textual space which carefully cultivates a rich intercultural dialogue between these communities of multiple belongings to unearth novel connections between gender and mobility.

The anthology -bilingual in format but with poetry in three languages - comprises an introduction by the editor and two main sections, "Morocco \& Ireland" and "Galicia \& Ireland", all preceded by a tailored calligraphic design by the Algerian plastic artist Hochemi Mokrane. Each section includes seven contributions by Moroccan and Galician writers, respectively, and are followed by their translations into English together with a response poem at the hands of fourteen Irish poets. Palacios' coupling of Mohammed Bennis \& Paula Meehan, Eva Veiga \& Maurice Harmon, or Gonzalo Hermo \& Keith Payne, to name a few, adumbrates the collection's aim to provide a holistic forum where both male and female poets from diverse generations and holding different positions within their respective social hierarchies and literary traditions come together to elaborate a pluralistic conversation. The high degree of original content together with the noticeably close collaboration among the creative writers resonates in the thematic cohesiveness of the volume as well as in the high literary quality of the translations.

The Moroccan contingent displays a wide array of voices, colors, and textures, united nonetheless in their penchant for evocative landscapes and conflicted lyric subjects. Starting on strong footing, the volume opens with "Laka al-turuq al 'adīda [The Lessons of Exile]" (2000) by Mohammed Bennis, ${ }^{1}$ a prominent voice of contemporary Arabic poetry, mediated and countered by the equally salient Irish poet Paula Meehan. Bennis delicately handles spatial tropes to explore the life lessons taught by exile, a theme that reverberates throughout the collection. Meehan's response, "By the Autumn River", thinks back through Bennis' motives to echo his view on painful instructiveness inherent to any journey into exile, yet significantly closes by suggesting its potential for "unlearning" - for deconstructing our notions of selfhood.

The following poems illustrate the processes of learning and unlearning during childhood, and their concomitant affective exile. Taha Adnan, himself a member of the Moroccan diaspora, distressingly conveys in "al-Māruksīluāz [The Maroxelloise]" (2009) the self-censorship of its heroine, a Moroccan girl from a traditional family growing up in multicultural Brussels. The pulsating verses relay the struggles of Adnan's "tongue twisted" hybrid to reconcile private desire and familial expectations, and culminates in painful encounters with the realities of the female body. In her response poem, Máighréad Medbh, 
too, portrays the social alienation of a dissident daughter. "All About Her" speaks of the expulsion and return of the lyric voice's anorexic sister from the very home in which she was punished for not conforming to her father's expectations of proper female conduct.

Fatima Zahra Bennis' "Naham [Longing]" (2008) and Susan Connolly’s “Anxiety", provide another two private yet opposing insights into the relationship between female desire and women's restricted self-determination. Bennis' verses express the longing for the right to desire without remorse in rebellious tones and through natural imagery. Connolly formally mirrors Bennis' two stanzas, but finds the equation of nature and woman oppressive.

Veering the anthology from intimate to political, Imane El Khattabi's "Fīl-harb [In the War]" and Hugh O'Donnell's "It Ain't Over" both allude to the current refugee crises. El Khattabi's poignant stanzas convey the devastating effects of the war through the continuum between material and emotional damages of a female refugee on her voyage to "a place untouched/by fire". Hugh O'Donnell resumes her life-story once established on the other side of the frontier. Read together, then, El Khattabi and O'Donnell's verses powerfully channel the chronicity of migration.

Memory and fantasy play complementary roles in the migrant's mental landscape. Mohamed Ahmed Bennis' "Khayāl bilā tarīq [Imagination without a Path]" (2012) addresses the migrant's disorientation when the memory of home wanes and technology proves a frustratingly inadequate means to quiet the migrant's sense of dislocation, leaving the imagination as sole source of comfort. Catherine Phil MacCarthy provides a prose reading of Bennis' poem as well as a response poem, "O Halloran's Fort", in which the poetic voice constructs an imaginary house "built with our own wit" in which to take shelter from real-life invasions.

In contrast, Aicha Bassry exposes how the migrant's imagination works both ways. Bassry's female persona in "Al-sābiha fîl- 'atash [Woman Swimming in Thirst]" (2014) is seated at a hotel room window overlooking the very boat that will take her away from her home country. If one reads the first stanza as expectant in tone, the second makes clear the woman's reservations towards the country of destination as she visualizes herself "on the opposite seashore, [...] a woman withering/ In a dark corner of life". Sarah Clancy responds in one of the most explicitly dialogic poems of this anthology, "Poem for a Migrant Poet Waiting to Make Her Crossing", with a lament of her own poetry's and her society's insufficiency to ease the migrant's ordeal, and a bid to poetic voices such as Bassry's: "please come poet with your poems and your art/come with your hope in the future/we have never needed you so much".

The curative potential of poetic exchanges between migrant and local communities is restated as the Moroccan section reaches an end in Mezouar El Idrissi's "Layl garnāța al-'ān [Tonight in Granada]" and Thomas McCarthy's "Reading 'Noche de Granada' of Mezouar El Idrissi". El Idrissi and McCarthy depart from the rest of the collection's predilection for borders to celebrate the cultural and literary bridges between "North and South".

The section "Galicia \& Ireland" broadens the anthology's horizons with two beguiling pieces about female transatlantic migrants by Cork-based poets Martin Veiga and Eiléan Ní Chuillenáin. Veiga's "Unha Casa na Habana [A House in Havana]" delves into a woman's vibrant reminiscences of her childhood home in the Cuban capital where she "nacín/por primeira vez ao mundo [was born the first time into the world]" to Galician migrants, and the distressing voyage towards her parents' home country. Entwining sensorial and oneiric imagery into her recollections, Veiga brilliantly captures the migrant's lasting affective attachment to a place from which she was so involuntarily detached. Ní Chuillenáin recovers her poem "She Was at the Haymaking" (2016) depicting a young Irishwoman's departure to a novitiate in America through layered images of restriction and release. 
Chus Pato and Lorna Shaughnessy set out on another radical shift in terms of perspective by conveying the experience of migration from the point view of those left behind. Pato's "Asun" (2010) recurs to unconventional cadence and line breaking to skillfully convey the tension between migrants' projection of success in the form of photographs and the ensuing sense of estrangement with their "voz totalmente inadecuada [voice that is completely out of place]" when the real conditions of the migrant are phoned home. In "Liberty Landing", Shaughnessy's lyric voice muses about the real and imagined photographs of a young Irish girl's wanderings in New York on her day off in contrast with her absence from the family albums.

Echoing Fatima Zahra Bennis' handling of female desire, subject matter and language in Eva Veiga's "sentir o corpo [to sense the body]" elude fixation in favour of free associations that fluctuate from the carnal to the spiritual, and back again, thereon scrutinizing one's conflicted relationship with the "brutal ocupación [brutish possession]" of the body. Maurice Harmon's response poem, "Fluttering Handkerchiefs" (2016), however, focusses on the recurrent concern in this collection with the lack of historical memory in the West. Harmon's last stanza, in particular, denounces the collective ostracism of refugees by the Irish, whose society is very much rooted in exile.

Baldo Ramos' "amada estranxeira [foreign beloved]" draws a picture of the frustrated attempts of a Galician family to settle down in post-Great Depression America. Ramos makes effective use of the image of the tree that is continuously uprooted and pruned as the family moves throughout the oxymoronic migrant space, "[o] noso definitivo/baleiro [our final void]". Evoking William Shakespeare's The Tempest, Celia de Fréine's "Doth Suffer a SeaChange" urges for a more empathetic encounter with the refugees that currently wash up on our shores. As Pato and Harmon, amongst others, de Fréine finds blame with the "false promises" that have fatally attracted migrants in the past and do still.

Gonzalo Hermo's self-reflexive "A estranxeira inventa a utopía [The outsider invents utopia]" (2011) is presented as an "acto de vinganza [act of vengeance]" against the poet's persisting recursion towards idealized, heteronormative muses. Hermo's "verso violento [violent lines] reject the "'árvore esquelética' ['skeleton tree']" and impositions that have conditioned, and castrated, the voices of the belligerent. Keith Payne renders Hermo's dialectics with remarkable vigor, yet his own contribution is exquisitely delicate. Paying homage to Manuel Rivas while also echoing Hermo's concerns, "The Outsider Watches the Woods from Her Room" depicts yet another female foreigner's perpetual liminality and silencing.

Marilar Aleixandre sets out to relocate her female personae to a lunar utopia in "auga na Lúa [moonwater]" (2016), where they are no longer forced to participate in or likened to the exploitation of the earth but in an empowering communion with nature. "The Path We Make with Our Feet Follows Us Everywhere", by Breda Wall Bryan moves through nondescript terrains as she depicts wrenching impressions of a migrant's flight plagued by loss, torture, and despair along every step of the way.

Migrant Shores closes as strongly as it opened with the already acquainted María do Cebreiro and Mary O'Donnell, whom fittingly offer similar accounts of two women's perambulations in red-light districts. In "O Barrio das Chinesas [The 'Cosmopolitan' Quarter]” (2005), very deftly reworded by O'Donnell, do Cebreiro expresses a woman's curiosity towards, admiration of, and identification with streetwalkers and cross-dressers. Multiple encounters with these harsh realities in this quarter prompt, however, a vision of emancipation: "Pero en toda prisión/hai unha reixa, e en toda reixa hai fendas [Yet in each prison/there are bars,/and between them are gaps]". O'Donnell's "Remembering Amsterdam" transports us to one of the most emblematic districts of sexual exploitation, where the lyric 
voice feels ashamed by her participation in the fetishizing of her fellow women. Recognizing culpability, as this poem evinces, is nonetheless also the first step towards solidarity.

The depth and breadth of Migrant Shores arises from a thoughtfully calibrated coordination of twenty-eight highly representative writers from Morocco, Galicia, and Ireland that endorses revisionist discourses on age-old questions such as conflict between selfhood and nationhood, body and state, poet and politics. The anthology fulfils its aim to make a substantial contribution towards (re)covering female voices and experiences as migrant bodies, but also towards broader, emergent discussions about (non-)belonging that have recently become so poignant in the context of resurgent xenophobia and the reinstatement of borders. As a whole, then, Migrant Shores constitutes an extremely rich network of poetic exchanges that is equally appealing to the general reader as well as to academic scholars in fields ranging from translation studies, comparative literature, trauma studies, or ecocriticism, amongst others.

\section{Notes}

${ }^{1}$ Since Migrant Shores anthologizes both new and previously published texts, those titles that have appeared elsewhere are followed here by their original year of publication within parentheses. See Palacios (2017: 127) for further details.

\section{Works Cited}

Elouafi, Jaouad, Bahi Takkouche, Manuela Palacios, and Arturo Casas Vales, eds. and trans. Los Ritos de Los Sentidos: Poesía Árabe. With calligraphies by Hachemi Mokrane. Madrid: Cantarabia, 2015.

O'Donnell, Mary and Manuela Palacios, eds. To the Winds our Sails: Irish Writers Translate Galician Poetry. Cliffs of Moher: Salmon Poetry, 2010.

Palacios, Manuela, ed. Forked Tongues: Galician, Basque and Catalan Women's Poetry in Translations by Irish Poets. Bristol: Shearsman, 2012.

Palacios, Manuela, ed. Six Galician Poets. Translated by Keith Payne. Todmorden, Lancs: Arc Publications, 2016.

Regina M. Ponciano is a PhD candidate at the Universidade de Santiago de Compostela, where she has also completed a BA in Modern Languages and Literatures (2014), a BA in English Language and Literature (2015), and an MA in Advanced English Studies (2016). Ponciano is currently working on her doctoral thesis on men's gender anxieties in late Victorian short fiction under the supervision of Dr. Jorge Sacido-Romero and Dr. Laura María Lojo-Rodríguez.

regina.ponciano@usc.es 
National Identities and Imperfections in Contemporary Irish Literature. Unbecoming Irishness

Edited by Luz Mar González-Arias

London: Palgrave Macmillan, 2017. 248 pp.

ISBN: 978-1-137-47629-6

\section{Reviewed by Giovanna Tallone (Independent scholar)}

In a world which always tends to very high standards, to perfection, in profession, career, social status, not to mention body and appearance, imperfection is a double-sided issue. The overtone of incompleteness, fault, blemish or deficiency embedded in the word can be disturbing, and yet it is a natural part of everyday life.

Such sense of disturbance comes to the fore in the title of the volume edited by Luz Mar González-Arias, National Identities and Imperfections in Contemporary Irish Literature, whose subtitle, Unbecoming Irishness, highlights an implication of instability in the role that the imperfect, the unsettling and the disconcerting have played in the fluidity of Irish identity throughout the Celtic Tiger years and beyond. The polarity between "identities" and "imperfections" creates a dynamic process that underlies the volume, marked by a stimulating multidisciplinary approach assembling a variety of essays on the general issue of imperfection in contemporary Irish literature from a variety of points of view. And diversity and variety underlie this collection, since the different contributors often provide a personal interpretation of the issue of imperfection.

The main concern of the volume is Irish literature, yet the "Foreword" is by Bridget Flannery, a painter and visual artist whose painting, "Days Beside Water", forms the cover of the volume. This stands out as a programmatic perspective in the cross-disciplinary stance of the book, drawing attention to what is irregular, and therefore enriching, in different facets of Irish society and different kinds of artistic perception. Her brief contribution - "On Irregularities" - sheds light on the objective of the collection, since "Irregularities help us to see more clearly" (xi).

The purpose of the book is to have a better insight into what is irregular thanks to its own imprecision or imperfection. "The odd catches the eye", writes Flannery, and this seems to provide a unifying motif to González-Arias's book in relation to Irish identity. The odd covers a variety of perspectives, which is underlined in the choice of the plural form in the title, Imperfections, from the lack of precision on language, to the imperfection of memory, to the instability of a rapidly changing society, to the corruption of the diseased body.

National Identities and Imperfections is organised into five different sections, each of them grouping from two to four essays, dealing with macro-topics: political and social imperfections, religious and familial dysfunction, corporeal and spatial oddities, with particular reference to disease, the limitation of stereotypes and distortion of Irishness. Part Five, an interview to writer Lia Mills, forms a companion piece to González-Arias's introductory Chapter One. Both provide a frame with mutual cross-references, and the interview in Part Five deals mostly with the imperfect in the creative sphere.

National Identities and Imperfections is holistic, in that it tries to provide a comprehensive approach to the issue of imperfection and to create an organized whole in which imperfection as such is scanned from different perspectives in the context of Irish literature and Irish society.

Comprehensiveness underlies Luz Mar González-Arias's introductory essay, "The Imperfect as a Site of Contestation in Contemporary Ireland", as the author covers a wide 
range of reflections on Irish literature and society, making reference to writers like John Banville, Marina Carr, Ceila de Fréine, and also to visual artists Amanda Coogan and Carmel Benson. González-Arias highlights the changes in Irish society, a context in which "representing the imperfect becomes a strategy of resistance" (4). As she points out, since the 2000s "the disquieting, the imperfect and the dystopian" have gradually gained a greater relevance in literary production, so that the act of writing itself fixes what is imperfect in contemporary Ireland. The multidisciplinary purpose of the essay is highlighted by the reproduction of works by Coogan and Benson.

Part One of the volume, "The Tiger and Beyond: Political, Social and Literary Fissures" combines a detailed psychological and socio-economic analysis of the Celtic Tiger and its aftermath with a reflection of its crisis in the literary scene. Ciarán Benson underlines the way in which the economic crisis following the boom of the 1990s also meant crisis in identity. His psychological stance is not disjointed from the awareness of the social, economic and political context that led to the lack of certainty in the years between 1999 and 2014 and the gradual deterioration of the faith in politicians and economists.

His detailed analysis paves the way for the two other essays in this section. Juan F. Elices focuses on Post Celtic-Tiger Ireland in Peter Cunningham's novel Capital Sins, exploring the complexities of the phenomenon of the Celtic Tiger through the use of satire. Cunningham's novel, writes Elices, provides a "caricaturesque vision of Ireland's most recent history" (3), pointing out the capital sins that mark the weaknesses of the country.

In her study of John McGahern's first and last novels, The Barracks and That They May Face the Rising Sun, Anita Morgan considers the imperfect as a state of incompleteness in Irish national identity in both novels. In particular, Morgan focuses on the imperfect in Ireland making reference to Fintan O'Toole's and John Water's identification of "selfdelusion as a failure of self-understanding" as "fundamental flaws" (51), which provides a reading key to McGahern's work.

The three essays of Part Two interrelate imperfection with the disruption of religion, family and marriage. Patricia Coughlan's study of sibling relations in some contemporary novels opens with the psychological and sociological analysis of family and siblings, considering the diversity of family types since 1990s, and then figures of siblings in Irish literature as a personification of the odd and the imperfect in an extended sense. Highlighting the role of literature in disclosing "fundamental issues in social thought" (69), Coughlan starts with Maeve Brennan's The Bride, defined as "a remarkable story of sibling displacement" (72), and then moves to more recent fiction by Colm Tóibín and Anne Enright, touching on poems by Eiléan Ní Chuilleanáin and Bernard O’Donoghue. In particular, Coughlan provides a remarkable juxtaposition between sibling song scenes in Joyce's Portrait and Enright's The Gathering, analysing parallels and contrasts. This gradually leads to a reflection on the issue of abuse in apparently normal relations in Enright's novel as a sign of the irregular and the disturbing that creates a bond between brother and sister.

A similar perspective is the focus of Marisol Morales Ladrón's essay on Emma Donoghue's Room, a novel that somehow recalls the experience of captivity in the cases of Natascha Kampusch and Elisabeth Fritzl, which came to public domain in 2006 and 2008. The mother-son dyad is explored as a form of resistance in appalling circumstances. Psychological resilience protects Jack and his mother in their survival to captivity, and yet their return to ordinary life is unsettling for the protagonists used to the room/prison which is also a home; it is also disturbing for a society unable "to face (the) difference and imperfection" (89) that marks mother and son in their return to normality.

Imperfection enters the world of religion and the Catholic Church in Auxiliadora Pérez-Vides's study of Mary Rose Callaghan's A Bit of Scandal. The Author focuses in 
particular on the stereotype of the "fallen sex" in the twenty-first century to provide an insight into the contradictions of double standards and the contrast between clerical credibility and female integrity (100). What is imperfect here is "the social ethos that targets and victimizes women" (101), as the story of Louise and her relation with the clerical figure of Peter provides a strong emphasis on gender and on the myth of the fallen woman that survives in the present.

In the four essays of Part Four - "Ex-Centric Bodies and Disquieting Spaces" attention shifts to the imperfection of disease and deformity in body, but also in space. Rui Carvalho Homem's sharp and sensitive study of pathology and poetics in Paul Muldoon's poetry juxtaposes the private grief of fatal disease and medical analysis to textual close reading. Muldoon's Horse Latidude of 2006 and Maggot of 2010 indulge on deformity and disease in the battle with cancer, and Carvalho Homem sees the biological growth or excess of life that characterizes cancer as a parallelism with Muldoon's textuality "proliferating on itself" (118).

Hedwig Schwall returns to Anne Enright in her psychoanalytical reading of Enright's fiction from the perspective of Bracha Ettinger's concept of matrixial borderspace. This perspective underlies Schwall's comprehensive analysis of Enright's work from her first short story collection The Portable Virgin to The Forgotten Waltz. Her attention to subjectivity highlights the strong presence of the issue of incompleteness and discrepancy in the "socalled phallic order" (131) in Enright's fiction, which provides a remarkable reading key in her extensive production.

Aida Rosende Pérez takes into account Emer Martin's Baby Zero, a novel on the imperfection of politics and confusion of immigration and unstable governments. Following Rosi Braidotti's conception of the monstrous as difference in the female body, Rosende Pérez draws attention to the imperfect in the female body, especially the pregnant body of immigrant women. The social contextualization of immigration intertwines with the character of the protagonist, Farah, who once in Ireland is a "migrant m/Other" (156), a sign of nonconformity in a country that has found itself a country of immigration rather than emigration.

Lucy Collin's attention moves from fiction to poetry and her essay "Changing Places: The Imperfect City in Contemporary Irish Poetry" provides a comprehensive overview and a deep analysis of the topic. Collins first considers the transformations in the Celtic Tiger years and the subsequent crisis to focus on role of the city and the urban space in poetry. The city is seen as both subject and object, and quoting Rebecca Solnit, Collins juxtaposes the city to a form of language which is running the risk of dying (167). She sensitively takes into account poems by Macdara Woods in his concern with the changing urban landscape, and by Thomas Kinsella in his attack to corruption in city planning. The instability embedded in the cityscape follows with the close reading of David Wheatley, Paula Meehan, Eavan Boland and Peter Sirr.

With Part Four, "Stereotypes and the Distortion of Irishness", attention moves to other aspects of identity and imperfection, as flaw and incompleteness are considered in the performing arts. Rosa González-Casademont takes into account a trope that combines identity and imperfection, considering the stereotype of the Irish drunkard not from a sociological but from an imagological perspective. After a survey of drinking culture as a conventional representation of identity, the author moves to drunken characters in Hollywood films over the decades. González-Casademont then concentrates on Irish/British productions, mentioning a wide range of titles and providing a perceptive insight that could attract the attention of the specialist and of the general reader.

Underlining the great success of Irish drama in the past twenty years or so, Shane Walshe draws attention to the possible problems in performance in terms of the Irish accent. 
After an overview of a variety of handbooks helpful for non-Irish actors to acquire the correct pronunciation in performance, he points out the potential confusion this implies.

Luz Mar González-Arias's volume concludes with her interview to Lia Mills, which in a way provides a sort of round-up for the collection. Its title, "Absolutely Imperfect" emphasises the purpose of the book and the interview interestingly combines a reflection of the imperfect and the incomplete in Irish history and society as "causes for shame" (223) linked to a "culture of silence" (224), with a very personal and intimate consideration of the serious illness that affected Mills a few years ago, leaving her physically "imperfect". Mills points out the role of fiction in the exploration of problematic issues as well as the gradual development of the genre of memoir in Ireland in the past few years, as it is the role of the artist to shed light in social or personal "dark corners" (225).

National Identities and Imperfections is an original work that proposes interesting readings of a variety of genres, often opening new ground and providing innovative suggestions and intepretations in the combination between literary and social studies. The issues discussed remain fresh in their multidisciplinary approach, which makes the volume a stimulating and significant contribution.

Giovanna Tallone is a graduate in Modern Languages from Università Cattolica del Sacro Cuore, Milan, and holds a PhD in English Studies from the University of Florence. An independent researcher and EFL teacher in secondary school, she has presented papers and published essays and critical reviews on Éilís Ní Dhuibhne, Mary O’Donnell, Mary Lavin, Clare Boylan, Lady Augusta Gregory, Brian Friel, Dermot Bolger, Vincent Woods and James Stephens. Her main research interests include Irish women writers, contemporary Irish drama, and the remakes of Old Irish legends.

giovanna.tallone@alice.it

Shaw: The Journal of Bernard Shaw Studies 37.1 (2017). Shaw and Classical Literature

Edited by Gustavo A. Rodríguez Martín

Pennsylvania: Penn State University Press, 2017.

\section{Reviewed by Audrey McNamara (University College Dublin, Ireland)}

This special issue of The Journal of Bernard Shaw Studies is a unique collection of six essays from eminent Shavian scholars dealing with what Rodríguez Martín describes, in his introduction to the volume, as the "deep ramifications" classical literature has "in Shaw's dramatic and non-dramatic discourse" (1). Rodríguez Martín creates a strong foundation for the volume by tracing Shaw's exposure to the classics from his "formative years through to the reverberations in the form of his critical reception, long after his death" (2). Quoting Shaw from Sixteen Self Sketches, Rodríguez Martín clearly demonstrates Shaw's interest, and indeed pride, in learning Latin, when in Wesleyan Connexional School he rose to the head of his class. (2). In exploring Shaw's engagement with music and in particular his interest in Wagner, and classical Greek sculpture, Rodríguez Martín underpins the very core of Shaw's writing, in all its forms. He describes The Quintesence of Ibsenism (1891) as Shaw's "early dramatic creed" (3) as it "showcases the influence of classical philosophers" (4). The 
evidence strengthens as examples of Shaw's allegiance to the classics is demonstrated frequently through the introduction, not least the mention of his meeting with Gilbert Murray, a leading classical scholar whom Shaw wrote to in 1940 commenting on the "revolutionary burst of playwriting activity in London" (6) telling him "the only ones likely to survive ... are the old Greek ones in your translations" (6). The introduction, which Rodríguez Martín states leans "toward the classical references in Shaw's critical writings" (7) creates a very effective forum for the discussions to follow on Shaw's dramatic work.

Nigel Slater investigates an interesting interpretation of Heartbreak House and its connection to antiquity in his essay "Nostoi and Nostalgia in Heartbreak House", aligning the notion of the "master metaphor of England as a ship" with the "classical trope of ship of state" (11) and Homer's Odyssey. He highlights the classical unity of time and place to further draw attention to Shaw's connection and interest in the classical form noting that all the action takes place over a twenty-four hour period in one place; the house. Slater creates a further strong link to classical Greek style by drawing interesting connections between Shaw's Heartbreak House and Plato's Republic. In keeping with the metaphor of the ship as a state, Slater considers the Platonic trope of a mutinous crew, who kill other sailors, keep the shipmaster "intoxicated or drugged" in relation to Shotover's insistence that "he drinks not for intoxication but to supress the dangers of sleep and dreams" (14). By returning to the parallels with the Odyssey and the trope of story-telling or "advantageous lies" (15), Slater highlights the connection of the other characters to the "Odyssean elements" (17) that are prominent in the play and further serve to strengthen his argument. He maintains that the Odyssean notion of "returning" or Nostoi are "important structuring elements of the narrative" (19) of the play and discusses the fact that "the characters keep returning to the stage" to speak to "a yearning for a return to an earlier state ... a cultured, leisured Europe before the war" (20). The essay provides much foundation and thought for the work that is to follow it.

Peter Gahan's "Bernard Shaw's Dionysian Tragedy" also deals with Heartbreak House but as part of a trilogy with Major Barbara and Misalliance. Gahan convincingly makes connections to how Shaw drew on Gilbert Murray's considered and perceptive translations of the classical plays, in particular "the Dionysian with its religious implications" (28). He acknowledges that "Shaw had begun drawing on Dionysian themes ten years before his encounter with Murray" (42) but argues that this only heightened his engagement with Murray's translations. Gahan's essay is divided into six sub topics that work well to draw out his argument on Shaw's use of Dionysian "religion" (29) in the plays under discussion. Interestingly, in creating an argument that binds Modernism to Dionysian, he ties the plays together stating that "Heartbreak House combines Misalliances play of sexual attractions with Major Barbara's weapons and explosives" (49). The richness and depth of this essay explores the historical and the biographical to form a very informative and strong argument not only for Shaw's appropriation of the classics but the influence Gilbert Murray had on his work. In his concluding section, "Shaw's Dramaturgy", Gahan contends that "Shaw used Euripides Bacchae as a type of palimpsest, on which to write three discursive plays on modern life" (59) but perhaps more importantly is his earlier assertion that "the importance of Shaw's dramaturgy, not to mention to the English speaking world of twentieth century modernism, of Shaw's exposure to Euripides through the medium of Murray would ... be hard to exaggerate" (39).

Matthew Yde constructively argues that "Plato was perhaps the greatest single influence on Shaw's political thinking as well as on his dramaturgical strategy" (75) in his essay "Dialectical Drama and the Ideal State: The Platonic Dimension of Shavian Dramaturgy and Political Theory". In referring to the school of thought that believes that "Plato was absolutely opposed to theatre" Yde reminds the reader of Plato's Republic and that it was 
always "his goal to provoke thinking" (76). His insightful essay is divided into two sections; Form and Content using several of Shaw's plays to argue astutely for the fact that the dramatic form for both men was "exploited for the higher purpose" of social reform (77). He effectively traces the effect of Socrates on Plato who, in turn, influenced Shaw creating a trichotomy of influence that can be seen in the "Shavio-Socratic dialogue - or dialectical argument" employed in examples of "Major Barbara, Misalliance and Getting Married" (81). Concluding his argument, he states that Shaw's plays reflect "his passion for reforming the world, the same passion that motivated his mentor, Plato" (96).

Daniel Leary's essay title is interesting and persuasive in itself, Virgilian Echoes: Arms and the Man and the Aeneid. As his argument unfolds the echoes become sounds and he convincingly draws parallels to the work of Virgil. Although Leary states in his introduction that the work is divided into four sections, there are just three headings: Literal, Allegorical, Moral but the final section is defined as the Anagoge in the opening sentence. Leary has a unique, informal and entertaining style of writing that demonstrates how a testing of ideas can arrive at a strong argument. He demonstrates great insight to Shaw's approach of "borrowing from the masters" (109) and argues that Shaw never allows "the action to be resolved" (111). Drawing comparisons, he maintains that in Virgil's Aeneid "the ending would continue to unsettle readers for two thousand years" (114) and believes that was as intentional on Virgil's part as it was with Shaw's approach to his own work. Interestingly, he does not conclude but grants, what he terms as an intermission, so that the reader can pause for thought on Shaw's use of the epic formula to convey how society is in reality rather than how it is idealistically perceived.

An appealing and substantiated link is made by Biljana Vlaskovicilic in her essay "Shaw's Joan of Arc and Heaney's Antigone" drawing Seamus Heaney and Bernard Shaw together in the use of classical literature in their work. Both Irishmen won the Nobel prize for literature, Shaw in 1925 and Heaney, seventy years later, in 1995. Vlaskovicilic convincingly draws comparisons between the reception of both men to the prize, Shaw's deliberate silence and Heaney's lack of sentimentality in his acceptance speech. Heaney's disillusionment with the political and social scene at the end of the twentieth century when he stated that "history is about as instructive as an abattoir" echoes Shaw's agreement with Hegel when he stated "that men never learn anything from history" (137). She argues that both playwright and poet "devoted their art to revealing the true face of humanity's "progress" (138). She draws on the historical, political and religious background of both men, and through a detailed analysis of Shaw's Saint Joan and Heaney's translation of Antigone, argues that though the men differ in respect of these, they both "often direct their attention to the classics and the past in search of a solution to the problems of the modern age" (139).

Kay Li's thought provoking consideration on Shaw's use of the classical myth in her essay "The Shavian Protagonists and Shaw's Changing Use of Classical Myths" argues that this ultimately led to him creating his own myth of "the Life Force and Creative Evolution" (156). She uses a little known play by Shaw, Passion Play (1878), to demonstrate the "embryonic Shavian Creative Evolution" (158) and maintains that "by the end of the nineteenth century, Shaw had already worked out quite a substantial theory on the Life Force and Creative Evolution" (162). Gilbert Murray's influence on Shaw again appears in the discussion through an analysis of, what Kay Li terms as "Shaw's most 'classical' play" (162) Major Barbara. However, Kay Li also discusses the attack on Gilbert's approach in 1915 when the "interest of the modernists in classical literature" (163) was aroused so that, by 1917, she contends that Shaw had begun to deconstruct the classical myths to make way for his own myth of the Life Force and Creative Evolution. An interesting reading on this 
deconstruction is taken on Heartbreak House and Back to Methuselah of which she argues that "the classical myths are exploded and pulled apart" (176).

Kay Li's concluding line "Through the Arcadian setting at the end of Back to Methuselah, Shaw shows that the gospel of Creative Evolution and the Life Force are as far as his thought can reach" (178) is a fitting final line for this important volume of essays in The Journal of Shaw Studies. Each essay, while different in style and thought process, contains important links with the others in the work and in so doing builds very strong evidence for Shaw's use of classical myths and literature in his writings, both dramatic and non-dramatic. This is further compounded by the useful and interesting "Selected Bibliography" of Shaw's reading material that Rodríguez Martín has chosen to complete the volume. There is no doubt that this collection will be invaluable to all researchers that are engaged with Shaw. An added bonus to the structure and depth of the volume is its appeal to all those interested in classical studies, whether they are Shaw scholars or not.

Audrey McNamara was awarded her PhD in Drama from University College Dublin and lectures there. Her monograph Bernard Shaw: From Womanhood to Nationhood - The Irish Shaw is forthcoming from Palgrave Macmillan. Publications include an essays on the work of Bernard Shaw, Conor McPherson, Enda Walsh and Benjamin Black. She wrote the programme note for the Abbey Theatre's production of Pygmalion (2014), and was a plenary speaker for the National Theatre of London's production of Man and Superman. She was guest co-editor with Nelson O'Ceallaigh Ritschel for Shaw 36.1: Shaw and Money (Penn State University Press 2016) and Shaw and Modern Ireland (Palgrave, 2017). She is also guest co-editor of The Eugene O'Neill Review Spring 2018 Edition (Penn State University Press).

neamh01@eircom.net

En busca de la Isla Esmeralda. Diccionario sentimental de la cultura Irlandesa Antonio Rivero Taravillo

Madrid: Fórcola, 2017. 440 pp.

ISBN: 978-84-16247-86-8.

\section{Reviewed by José Francisco Fernández (University of Almería, Spain)}

It must have been exhilarating for the translator and poet Antonio Rivero Taravillo to write this entertaining and highly engaging dictionary of all things Irish. Being a "vocational Irishman", as he has defined himself in interviews, he was absolutely free to fill these pages with his vast knowledge of Irish history and culture, liberated from the pressure of academic writing. To the formal dictates conveyed by the term "dictionary" in the title, the word "sentimental" has been conveniently added, as a way of indicating that the author intends to follow his fancy in this panoramic view of Ireland. This, in fact, is the key to understand such an author's dictionary; as in similar cases, Rivero Taravillo is free to devote a dozen pages to a favourite writer, for instance, while ignoring those individuals or events that he is not interested in, although admittedly his gaze is quite comprehensive. Furthermore, he makes clear in the second page of the introduction that he has interspersed the explanations of terms 
with personal accounts, which makes his engagement with Ireland even more focused through the particular lens of the author. The reader is warned, therefore, that this is not exactly an encyclopedia about Ireland, but rather the testimony of a profound passion (8). The introduction, "Hibernofilia", is most relevant in that it includes his mission statement. Here Rivero Taravillo defines the passion for Ireland as a malady which is rarely fatal and which affects millions of people throughout the world. He also admits that the composition of this dictionary was prompted by the publication of the highly acclaimed Pompa y circunstancia. Diccionario sentimental de la cultura inglesa (2015), by Ignacio Peyró, also published by Fórcola. He introduces a further caveat for readers when, at the end of the prologue, he hopes that the book will not be judged by its shortcomings or absences, but by what may crop up unexpectedly and surprise the reader (in my case, Ludwig Wittgenstein's sojourns in Ireland).

There was in any case no need for the author to display such caution; his dictionary is certainly a personal account, but it is also full of erudition. In this sense the reader should not be deceived by the multiple anecdotes that abound in the volume, nor by Rivero Taravillo's colloquial style. There are long hours of reading (and listening) in the 440 pages of the dictionary, and this inevitably shows in the composition of the entries.

Rivero Taravillo is no newcomer to Irish Studies. As a translator he has rendered into Spanish works by Jonathan Swift, W.B. Yeats, Jamie O'Neill and Kate O'Brien, among others. He taught himself Gaelic in order to translate An béal bocht (The Poor Mouth) by Flann O'Brien, one of his favourite authors. A compilation of what he has learned from various visits to Ireland, and from reading and translating Irish authors, has naturally produced something very fine, and En busca de la Isla Esmeralda is remarkable for its breadth of knowledge and its passionate intensity. Rivero Taravillo's dictionary is particularly effective in conveying information about Irish folklore, an area of knowledge not commonly found in books on Ireland published in Spain. The entries on Béaloideas, the journal of the Folklore of Ireland Society; Míchéal Ó Muircheartaigh, radio broadcaster of Gaelic sports; Seán Ó Ríordáin, poet; Tomás Ó Criomhthain, memorialist of the Blasket Islands; Máirtín Ó Direáin, poet, as well as those on GAA, Gaeltacht, Oireachtas, Fleadh and Dindshenchas, among many others, all make this book an invaluable source of information on Gaelic themes for Spanish readers, and by someone who definitely knows what he is talking about. The book also deals with Irish music, and this again is the product of the author's curiosity and passion. The Chieftains, The Pogues, Christy Moore, Liam Clancy and Sinéad O'Connor are of course represented with judicious entries, but there are also items on artists far less well-known to a general Spanish readership, such as composers Seán Ó Riada and Mícheál Ó Súilleabháin, singer Ronnie Drew and musician Tommy Makem; all of these receive lengthy appreciations by the author. I particularly enjoyed the way he dispatches U2 with the single laconic sentence: "Ese grupo famoso" (385). Again, this is what is most valued in a personal dictionary, the sense of accompanying the author through an extended tour of his likes, dislikes, and, most importantly, his passions.

Rivero Taravillo does not fail to pay tribute to a considerable number of Irish writers, including John Banville, Samuel Beckett, Brendan Behan, Maeve Binchy, Eavan Boland, Elizabeth Bowen, Seamus Heaney, James Joyce, Nuala Ní Dhomhnaill, Frank McCourt, Louis Mac Niece, John Montague, Kate O’Brien, Colm Tóibín, among many others. It has been a pleasant surprise for this reviewer to see that favourite authors, such as Aidan Higgins and Pearse Hutchinson, are also featured in the book. There are of course some names missing, inevitable even in scholarly dictionaries of literature, and indeed the author warned about such absences in the introduction. Still, I have the feeling that Evelyn Conlon, Éilís Ní Dhuibhne, John McGahern and William Trevor, plus a few others, could easily have made appearances in the book, and their presence would have further enhanced the rich literary 
texture of the dictionary. In a project of this kind, a work by someone with a clear vision and commitment to the cause, an engagement with the authors he admires (and Rivero Taravillo engages with them splendidly) easily compensates for the necessary absences.

The dictionary is also a fine source of information on Irish history and politics. Mary Robinson does not have an entry of her own, although she is mentioned a few times here and there. Rivero Taravillo, however, includes a long commentary on Éamon de Valera. He expands on the Spanish origins of the person who would become Taoiseach and President of the Irish Republic for many years. It is well-documented that de Valera's father was Spanish, but little is known about his life. Rivero Taravillo has consulted different sources and has done his own research in archives, tracing the origins of the Valera family to the city of Cabra, in the province of Córdoba. This is in contrast to the claim made in the latest biography of the Irish politician, A Will to Power. Éamon de Valera (2015) by Ronan Fanning, where it is stated that "Vivion de Valera [Éamon's father] had been born in 1853 in Spain's Basque country, where his father was an army officer who later brought his family to Cuba where he worked in the sugar trade between Cuba, Spain and the United States" (3). Fanning does not provide any evidence to support this assertion. Rivero Taravillo has done work on family documents and he has found someone who would conform to the profile of the military man-turned-entrepreneur mentioned above and he would not be de Valera's grandfather, but a distant relative born in Cabra. In Rivero Taravillo's account, Éamon de Valera's grandfather was born in Seville, just like his son, Antonio Juan Vivion [de Valera]. The latter was trained as a sculptor in Seville, studying art in Madrid and Paris before emigrating to New York, where he met Kate Coll, an Irish young woman who worked as a maid for a rich family. The chronicle of the fortunes of the politician's father in En busca de la isla esmeralda is necessarily tentative, the figure of the progenitor is lost in the mists of time, but Rivero Taravillo's findings have been contrasted with the opinions of different experts.

Additionally, the dictionary is sprinkled with a refreshing assortment of locations from Irish geography. Perhaps in a few entries the author moves on a little hastily and does not provide the necessary nuances: More Pricks than Kicks (1934) by Samuel Beckett, is mentioned, but does not consist of stories of student life (49); the translator of Ray Bradbury's poetry into Spanish is not López García, as claimed, but Gómez López (67); and, again contrary to what is claimed, there is thus far no evidence that Flann O'Brien visited Germany (279). Yet, these are very minor details that amount to very little in contrast to such a magnificent achievement. Rivero Taravillo's dictionary conveys a contagious enthusiasm for Ireland and it should be strongly recommended. It is, above all, a good read.

One is of course tempted to compare Rivero Taravillo's book with the now classic and pioneering Diccionario cultural e histórico de Irlanda, by J. A. Hurtley, B. Hughes, R. M. González Casademont, I. Praga and E. Aliaga (1996), a volume that is now sadly out of print. The dictionary by Hurtley et al. has for many years been the only reliable reference source on Irish culture in the Spanish language, used by a whole generation of scholars who were studying for their English degrees or just setting out on doctoral research when it was published, and who are now senior lecturers in universities across Spain. It is, so to speak, the dictionary of the founding fathers (mostly mothers, actually) of Irish Studies in Spain. It is rigorous, systematic, meticulous and precise. The Diccionario sentimental de la cultura irlandesa by Rivero Taravillo is equally reliable and has the added bonus of the author's personal touch. In an ideal world, students and readers with a passion for Ireland should be encouraged to use both. 


\section{Works Cited}

Fanning, Ronan. A Will to Power. Éamon de Valera. London: Faber, 2015.

Peyró, Ignacio. Pompa y circunstancia. Diccionario sentimental de la cultura inglesa. Madrid: Fórcola, 2015.

Hurtley, J. A., B. Hughes, R. M. González Casademont, I. Praga and E. Aliaga. Diccionario cultural e histórico de Irlanda. Barcelona: Ariel, 1996.

José Francisco Fernández is Senior Lecturer in English literature at the University of Almería, Spain. His most recent work focuses on the narrative of Samuel Beckett and his reception in Spain, including articles on Beckett published in specialized journals such as Journal of the Short Story in English, Journal of Beckett Studies, AUMLA, Studi Irlandesi and Arcadia, among others. He has also translated into Spanish three novels and one collection of short stories by Samuel Beckett. He teaches Anglo-Irish literature in the Master's Degree in English Studies at the Spanish Open University (UNED) and is general editor of the journal Estudios Irlandeses.

jffernan@ual.es 